\title{
Growth analysis and land equivalent ratio of fenugreek- buckwheat intercrops at different fertilizer types
}

\section{Wachstumsanalyse und Flächenäquivalenz von Gemengen aus Bockshornklee und Buchweizen bei unterschiedlichen Düngerarten}

\author{
Aliyeh Salehi $^{12 *}$, Sina Fallah ${ }^{1}$, Reinhard W. Neugschwandtner ${ }^{2}$, Bano Mehdi², Hans-Peter Kaul $^{2}$
}

\author{
${ }^{1}$ Faculty of Agriculture, Shahrekord University, Rahbar Bolvar, 64165478 Shahrekord, Iran \\ ${ }^{2}$ Division of Agronomy, Department of Crop Sciences, University of Natural Resources and Life Sciences Vienna (BOKU), Konrad-Lorenz- \\ Straße 24, 3430 Tulln, Austria \\ * Corresponding author: aliyeh.salehi@boku.ac.at
}

Received: 29 March 2018, received in revised form: 24 July 2018, accepted: 27 July 2018

\begin{abstract}
Summary
Intercropping can increase crop growth and yield due to improved resource use efficiency. A two-year field experiment was performed in Shahrekord (Iran) to determine the effect of crop stand composition and fertilizer type on the productions of aboveground dry matter and growth parameters of fenugreek-buckwheat intercrops. Sole crops of fenugreek (F) and buckwheat (B) were compared to the three substitutive intercropping ratios $(\mathrm{F}: \mathrm{B}=2: 1,1: 1$ and 1:2). Crop stands were fertilized with chemical fertilizer or broiler litter. Fenugreek could produce in intercrops a similar amount of above-ground dry matter compared to its corresponding share on the sowing ratio. Contrary to that, buckwheat could produce in intercrops more above-ground dry matter than its share on the sowing ratio, especially with a low to medium share of buckwheat. Consequently, the intercrops with F:B (2:1) and F:B (1:1) had an above-ground dry matter yield advantage compared to the pure crop stands of both crops. Broiler litter was more effective in increasing the growth rates and thus the above-ground dry matter production compared to the chemical fertilizer. Thus, growing fenugreek and buckwheat in intercrops fertilized with broiler litter can be beneficial for increasing the biomass production in semiarid environments.
\end{abstract}

Keywords: Intercropping, growth rate, above-ground dry matter, broiler litter, chemical fertilizer

\section{Zusammenfassung}

Der Gemengeanbau kann zu höherem Pflanzenwachstum und Biomasseerträgen aufgrund einer verbesserten Resourcennutzung führen. Ein zweijähriger Feldversuch wurde in Shahrekord (Iran) durchgeführt, um den Einfluss von Pflanzenbestand und Düngerform auf den Ertrag der oberirdischen Biomasse und die Wachstumsparameter von Gemengen aus Bockshornklee (F) und Buchweizen (B) zu untersuchen. Reinbestände von Bockshornklee und Buchweizen wurden mit drei substitiven Gemengen $(\mathrm{F}: \mathrm{B}=2: 1,1: 1$ and 1:2) verglichen. Die Pflanzenbestände wurden mit Mineraldünger oder Hühnermist gedüngt. Bockshornklee konnte in den Gemengen einen ähnlichen Anteil an oberirdischer Biomasse im Vergleich zum Saatanteil produzieren. Hingegen konnte Buchweizen in den Gemengen einen höheren Anteil an oberirdischer Biomasse im Vergleich zum Saatanteil produzieren, insbesondere bei geringem bis mittlerem Anteil an Buchweizen. Folglich hatten die Gemenge mit F:B (2:1) und F:B (1:1) einen Ertragsvorteil bei der oberirdischen Biomasse gegenüber den Reinsaaten der beiden Kulturpflanzen. Hühnermist konnte die Wachstumsparameter und somit die Produktion der oberirdischen Biomasse effizienter erhöhen als Mineraldünger. Somit ist der Anbau von Bockshornklee und Buchweizen in Gemengen mit Hühnermistdüngung vorteilhaft für die Steigerung der Biomasseproduktion in semi-ariden Umwelten.

Schlagworte: Gemengeanbau, Wachstumsrate, oberirdische Biomasse, Hühnermist, Mineraldünger 


\section{Introduction}

There is an increasing interest to diversify the agricultural production systems in order to enhance several valuable eco-agricultural strategies, such as to produce sufficient food and feed, to obtain higher crop protection, to increase biodiversity and increasingly to meet the requirements of sustainable intensification. Intercropping can be a solution to diversify agroecosystems by using more leguminous crops and also applying less mineral fertilizers (Kübler et al., 2006; Gomiero et al., 2011; Branca et al., 2013; Zając et al., 2013; Neugschwandtner and Kaul, 2014; 2015).

Previous studies indicated that growing crops in intercrops is an important strategy for enhancing sustainability and yields, as well as to improve soil conservation (Zając et al., 2013; Branca et al., 2013; Klimek-Kopyra et al., 2015; Scalise et al., 2015). Reasonable intercropping could increase crop growth and productivity (Cecilio et al., 2011), efficient use of the resources water, nitrogen and radiation (Lithourgidis et al., 2011), macronutrients (Kübler et al., 2010; Neugschwandtner and Kaul, 2016a; Salehi et al., 2018) and micronutrients (Neugschwandtner and Kaul, 2016b), yield quality (Klimek-Kopyra et al., 2017) and lower the damage caused by diseases and pests (Hauggaard-Nielsen et al., 2001). However, yield decreases in intercropping have also been reported (Ebrahimi et al., 2017). Functional groups or typical species used in intercropping include legumes (e.g., clover, fenugreek, vetch, beans and peas) and non-legumes (e.g., barley, buckwheat, rye, oat, wheat and flax) (Petropoulos, 2002; Hamzei and Seyyedi, 2016). Advantages of intercropping legumes with non-legumes are explained by the complementary use of resources due to non-competition for the same resource niche (Bedoussac and Justes, 2010).

Fenugreek (Trigonella foenum-graecum L.) is a small-seeded annual legume crop, originally grown from Eastern Europe to Central Asia. It is grown today in many parts of the world as a spice or forage crop (Kenny et al., 2013). Fenugreek seeds are known for their health benefits including anti-diabetic, anti-obesity and anti-carcinogenic effects (Handa et al., 2005; Raju and Bird, 2006), and they are also used to flavor many foods (Betty, 2008). Fenugreek is a suitable plant for intercropping due to its ability to support the biological nitrogen fixation of rhizobia and its subsequent improvement of soil fertility (Petropoulos, 2002; Dadrasan et al., 2015).

Common buckwheat (Fagopyrum esculentum M.) is a non-legume crop belonging to the family of Polygonaceae
(Koyama et al., 2013). It is an important crop in organic farming (Kalinova and Vrchotova, 2011) with important medical characteristics as well as a high nutritional value. Buckwheat seeds are rich in natural antioxidants, digestible proteins, vitamins, minerals, favorable fatty acids, flavonoids (rutin, catechins) and dietary fiber (Halbrecq et al., 2005; Alamprese et al., 2007).

Nitrogen $(\mathrm{N})$ is plant's most required nutrient that plays an essential role for growth and crop yield (Yin et al., 2014). $\mathrm{N}$ fertilization increases the values of growth rates (Sugár et al., 2017). Fertilizer requirements and nutrient use efficiency in intercropping are still important research issues and may be different compared to sole crops (Ghosh et al., 2009). Ghosh et al. (2009) reported that dry matter production in sole sorghum and soybean-sorghum intercropping was significantly improved with the increase in NPK rates. Applying high rates of chemical fertilizer to increase growth and yield will not only lead to increased production costs, but may also lead to environmental pollution and a reduction of soil health (Peng et al., 2010; Ahmadian et al., 2011). Furthermore, it may not be possible to supply sufficient $\mathrm{N}$ at suitable times to meet the plant demand for $\mathrm{N}$ by relying on chemical fertilizer as the only source of $\mathrm{N}$ (Ahmadian et al., 2011). In order to decrease chemical fertilizer inputs while keeping crop yields high, ecosystem functions (i.e., nutrient cycling) that are disturbed must be restored (Damour et al., 2012). One important strategy for this is to use fertilizer alternatives, such as manure or other organic amendments (Stockdale et al., 2002; Tejada and Gonzalez, 2008). Organic fertilizers release nutrients over time due to not only their high content of micronutrients and minerals but also their slower release and therefore longer lasting availability. The application of organic manure is more effective and positive compared to chemical fertilizer in improving the quality and fertility of the soil, soil nutrient exchange capacity, soil ecological processes, soil health and crop productivity (Fereidooni et al., 2013; Shrestha et al., 2013; Bajelia et al., 2015, Salehi et al., 2017a). The application of farm yard manure has been shown to have a beneficial effect on the growth parameters of fenugreek. The dry matter accumulation and crop growth rate (CGR) were significantly higher with increasing doses of farmyard manure (up to $15 \mathrm{t} \mathrm{ha}^{-1}$ ) at all stages of crop growth (Khiriya et al., 2002). Mirhashemi et al. (2009) demonstrated for ajowan (Carum copticum) and fenugreek grown organically in pure stands and intercrops that the CGR of ajowan was highest in double-row intercrops and the dry matter production was highest in 
triple-row intercrops, while for fenugreek, the triple-row intercrops had the highest CGR and the single-row intercrops had the highest dry matter. Both dry matter production and CGR were increased by farm yard manure for ajowan and fenugreek.

Cultivation systems are often evaluated and compared to the sole crops using the land equivalent ratio (LER). Salehi et al. (2017b) reported that LERs of intercropped fenugreek-buckwheat varied from 0.99 to 1.72 with the highest LER in F:B (2:1) treated with broiler litter.

While the efficient utilization of the available resources by legume/non-legume intercropping systems has been shown as mentioned above, the diverse influence of organic and inorganic fertilizer on growth parameters in intercropping systems is poorly researched and only scarce information is available on fenugreek-buckwheat intercrops grown under different fertilization regimes. Therefore, we assessed how the application of organic and chemical fertilizer can improve plant growth in both sole and intercropped fenugreek and buckwheat. In the present study, the objectives were to assess: (1) above-ground dry matter (AGDM) production, (2) crop growth rate (CGR), (3) relative growth rate (RGR) and (4) land equivalent ratio of the above-ground dry matter (AGDM-LER) of fenugreekbuckwheat intercrops compared to the corresponding sole crops as affected by sowing ratio and fertilizer type. A comprehensive assessment of seed yield, yield components, nutrient use efficiency and nutrient land equivalent ratio is provided in Salehi et al. (2017b) and Salehi et al. (2018).

\section{Materials and methods}

\subsection{Experimental site and treatments}

The field experiment was performed at the research farm of Shahrekord University $\left(32^{\circ} 21^{\prime} \mathrm{N}, 50^{\circ} 49^{\prime} \mathrm{E}\right.$; $2050 \mathrm{~m}$ a.s.l.) of Iran, in the years 2014 and 2015. This twofactorial experiment in a randomized complete block design was conducted with three replications. The first factor was the cropping system with five levels: sole cropping of fenugreek $(\mathrm{F})$, sole cropping of buckwheat $(\mathrm{B})$ and three substitutive intercropping ratios $(\mathrm{F}: \mathrm{B}=2: 1-$ two rows of fenugreek + one row of buckwheat; $1: 1$ - one row of fenugreek + one row of buckwheat and 1:2 - one row of fenugreek + two rows of buckwheat). The second factor was $\mathrm{N}$ fertilizer type with two levels: chemical fertilizer (CF) or broiler litter (BL). The amount of nitrogen applied was
$60 \mathrm{~kg} \mathrm{~N} \mathrm{ha}^{-1}$ for buckwheat and $80 \mathrm{~kg} \mathrm{~N} \mathrm{ha}^{-1}$ for fenugreek, respectively. The broiler litter application of 7.5 to $10 \mathrm{Mg} \mathrm{ha}^{-1}$ provided on annual average 60 and $80 \mathrm{~kg} \mathrm{~N}$ $\mathrm{ha}^{-1}$, respectively, assuming $50 \%$ mineralization of broiler litter $\mathrm{N}$ under the given environmental conditions in the Shahr-e Kord region (Alizadeh et al., 2012). In the chemical fertilizer treatments, urea was applied. Phosphorus (P) was applied as triple superphosphate, and $\mathrm{Fe}, \mathrm{Mn}, \mathrm{Cu}$, and $\mathrm{Zn}$ were applied to the urea-fertilized plots at a rate equivalent to the total amounts added by the broiler litter treatments in order to compensate for the nutrient inputs of these elements with the organic fertilizer. In the integrated fertilizer treatments, $50 \%$ of chemical fertilizer and 50\% of broiler litter was applied to each plot.

Detailed information on the environmental conditions, analysis of soil and broiler litter, experimental design, experimental set-up and management are given in Salehi et al. (2017b) and Salehi et al. (2018).

\subsection{Growth analysis and land equivalent ratio and calculations}

Fenugreek and buckwheat crops were sampled to determine above-ground dry matter (AGDM) by randomly harvesting plants of each crop at 10-day intervals starting from HD 1 ( $\mathrm{HD}=$ harvest date) until final harvest (HD 7) (Table 1). The plant samples were oven-dried at $65^{\circ} \mathrm{C}$ for $72 \mathrm{~h}$ to obtain a constant weight. Crop growth rate (CGR) and relative growth rate (RGR) were calculated for each period between subsequent harvest dates according to Hunt (1982) as follows:

(1) CGR $\left(\mathrm{g} \mathrm{m}^{-2} \mathrm{~d}^{-1}\right)=\left(\mathrm{W}_{2}-\mathrm{W}_{1}\right) /\left(\mathrm{t}_{2}-\mathrm{t}_{1}\right)$

(2) $\operatorname{RGR}\left(\mathrm{mg} \mathrm{g}^{-1} \mathrm{~d}^{-1}\right)=\left(\ln \mathrm{W}_{2}-\ln \mathrm{W}_{1}\right) /\left(\mathrm{t}_{2}-\mathrm{t}_{1}\right)$

where $\mathrm{W}_{2}$ and $\mathrm{W}_{1}$ represent the final and initial dry weight, and $t_{2}$ and $t_{1}$ indicate the end and the start day of each period.

The land equivalent ratio (LER) indicating the possible yield advantages of intercrops of the above-ground dry matter at each harvested date was calculated according to Mead and Willey (1980) as follows:

(3) $\operatorname{LER}=\left(\mathrm{Y}_{1.2} / \mathrm{Y}_{1.1}\right)+\left(\mathrm{Y}_{2.1} / \mathrm{Y}_{2.2}\right)$

where $\mathrm{Y}_{1.1}$ and $\mathrm{Y}_{2.2}$ are the above-ground dry matter for crop 1 and crop 2 grown in sole cropping and $Y_{1.2}$ and $Y_{2.1}$ are the yields of the crops grown in intercropping. The LER 
is the sum of the partial LERs of the individual crops in the intercropping. A LER $>1$ indicates a production advantage of the intercropping system, whereas a LER $<1$ indicates a production disadvantage. Partial LERs show the relative competitive abilities of individual crops in the intercropping.

\subsection{Statistics}

An analysis of variance for the two factorial experiments was performed on data from each year considering intercropping ratio as the first factor and $\mathrm{N}$ source as the second factor by using SAS version 9.2. Means were separated by least significant differences (LSD), when the F-test indicated factorial effects on the significance level of $\mathrm{p}<0.05$.

\section{Results}

\subsection{Above-ground dry matter}

\subsubsection{Total above-ground dry matter of crop stands $\left(\mathrm{AGDM}_{\mathrm{T}}\right)$}

For all harvest dates, the total above-ground dry matter $\left(\mathrm{AGDM}_{\mathrm{T}}\right)$ in both years was significantly affected by crop stand $\times$ fertilizer type (Figures $1 \mathrm{a}-\mathrm{d}$ ). $\mathrm{AGDM}_{\mathrm{T}}$ increased for all the crop stands exponentially up to HD 4 and then started to level off. $\mathrm{AGDM}_{\mathrm{T}}$ was generally highest in $\mathrm{F}: \mathrm{B}$ $(2: 1)$ in both years and with both fertilizer treatments. In 2014, in the chemical fertilizer (CF) treatment, the AG$\mathrm{DM}_{\mathrm{T}}$ of $\mathrm{F}: \mathrm{B}(2: 1)$ had the highest values, followed by $\mathrm{F}: \mathrm{B}(1: 1)$ which had significantly higher values than Sole F, Sole B and F:B (1:2). For the BL treatment, F:B (2:1) had significantly higher $\mathrm{AGDM}_{\mathrm{T}}$ than the other four crop stands from HD 4 onward (Figures $1 \mathrm{a}-\mathrm{b}$ ). In 2015, in the CF treatment, the $\mathrm{AGDM}_{\mathrm{T}}$ was from HD 6 onwards ranked from highest to lowest as follows: F:B (2:1), F:B $(1: 1)>$ Sole F > Sole B, F:B (1:2). For BL from HD 4 onward, the values were ranked as follows: $F: B(2: 1)>$ Sole $B$, F:B $(1: 1)>$ Sole F, F:B (1:2) (Figures $1 \mathrm{c}-\mathrm{d}$ ).

On the final harvest date (HD 7) in 2014 with CF, the $\mathrm{AGDM}_{\mathrm{T}}$ of $\mathrm{F}: \mathrm{B}(2: 1)$ was $54 \%$ and $107 \%$ higher compared to the second best and the worst yielding crop stand, respectively. In 2014 with BL, the differences were 34\% and $41 \%$, respectively. In 2015 with CF, the differences were $7 \%$ and $70 \%$, respectively, and in 2015 with BL, the differences were $25 \%$ and $61 \%$, respectively. On average overall crop stands at $\mathrm{HD} 7, \mathrm{BL}$ increased $\mathrm{AGDM}_{\mathrm{T}}$ by $13 \%$ in 2014 and by $19 \%$ in 2015 , compared with CF.

\subsubsection{Above-ground dry matter of fenugreek $\left(\mathrm{AGDM}_{\mathrm{F}}\right)$ or buckwheat $\left(\mathrm{AGDM}_{\mathrm{B}}\right)$}

The above-ground dry matter of fenugreek is shown in Figures $1 \mathrm{e}-\mathrm{h}$ and of buckwheat in Figures $1 \mathrm{i}-\mathrm{l}$. In 2014, at the early growth stage (HD 1), the $\mathrm{AGDM}_{B}$ was much higher than that of $A_{G D M}$ In the pure crop stands, Sole F had a lower AGDM than Sole B with CF up to HD 3 and also with BL up to HD 4. Final AGDM, however, did not differ between Sole F and Sole B. In 2015, AGDM of Sole F was lower with CF up to HD 4 but higher for Sole F from HD 6 onward, whereas it was lower for Sole F than for Sole B with BL throughout the vegetation period.

A significant interaction of crop stand $\times$ fertilizer type was observed for $\mathrm{AGDM}_{\mathrm{F}}$ at all the harvest dates in 2014 and for some harvest dates in 2015 (Figures 1 e-f). For all the harvest dates in 2014, $\mathrm{AGDM}_{\mathrm{F}}$ was ranked in both CF and BL treatments as followed: Sole F > F:B (2:1) >

Table 1. Sowing and harvest dates (HD) of fenugreek and buckwheat in 2014 and 2015

Tabelle 1. Anbau- und Erntetermine von Bockshornklee und Buchweizen in den Jahren 2014 und 2015

\begin{tabular}{|c|c|c|c|c|c|}
\hline Dates & Crops & 2014 & DOY $^{1}$ & 2015 & DOY \\
\hline Sowing & F, B & 29 May & 149 & 23 May & 143 \\
\hline HD 1 & F, B & 8 July & 189 & 3 July & 184 \\
\hline HD 2 & F, B & 18 July & 199 & 13 July & 194 \\
\hline HD 3 & F, B & 28 July & 209 & 23 July & 204 \\
\hline HD 4 & F, B & 7 August & 219 & 2 August & 214 \\
\hline HD 5 & F, B & 17 August & 229 & 12 August & 224 \\
\hline HD 6 & F, B & 27 August & 239 & 22 August & 234 \\
\hline \multirow{2}{*}{ HD 7} & B & 6 September & 249 & 1 September & 244 \\
\hline & $\mathrm{F}$ & 12 September & 255 & 15 September & 258 \\
\hline
\end{tabular}

${ }^{1} \mathrm{DOY}=$ day of year 


\section{Chemical fertilizer Broiler litter $\quad$ Chemical fertilizer $\quad$ Broiler litter Fenugreek+Buckwheat}
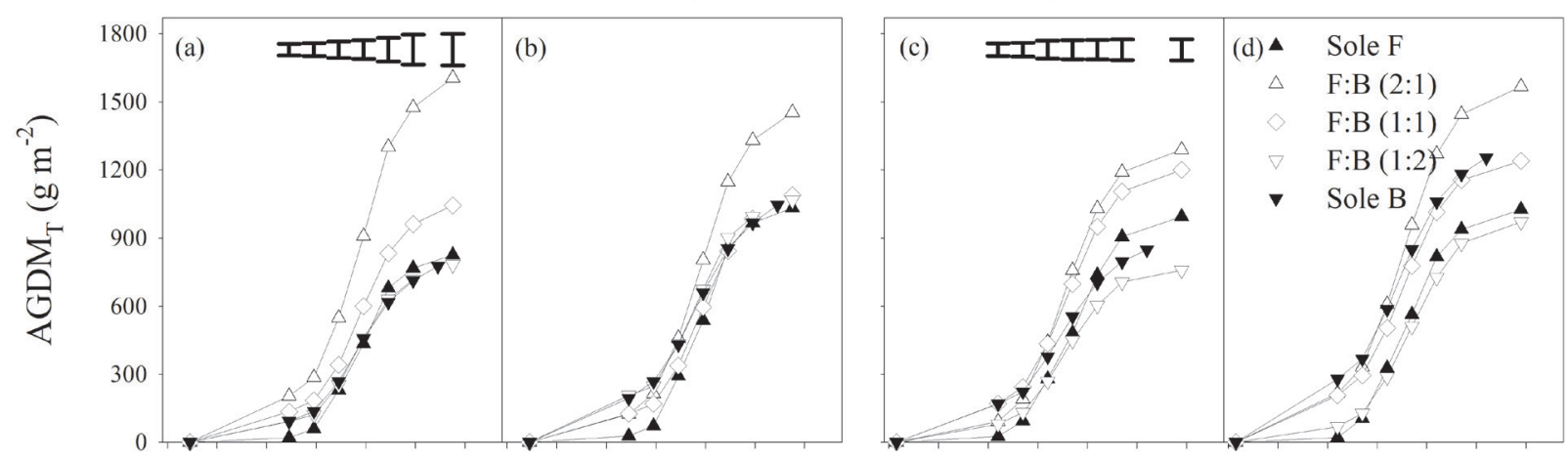

Fenugreek
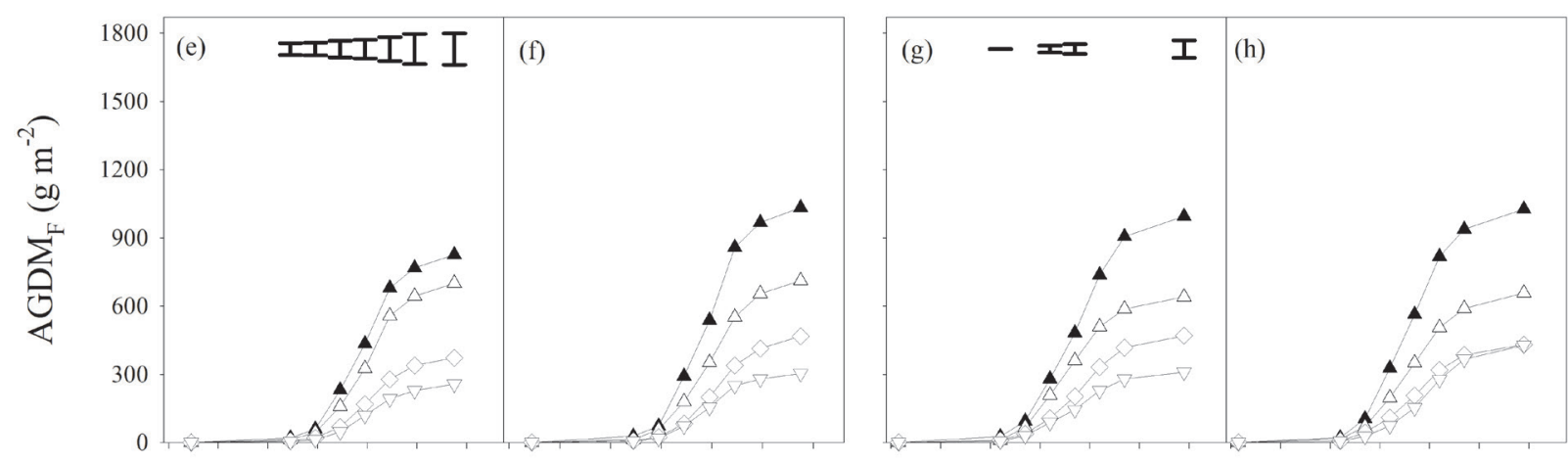

Buckwheat

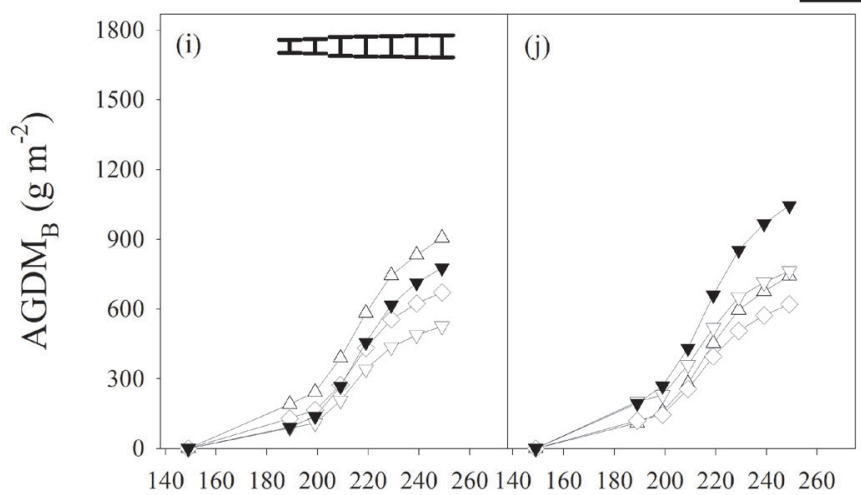

days of year

day of year

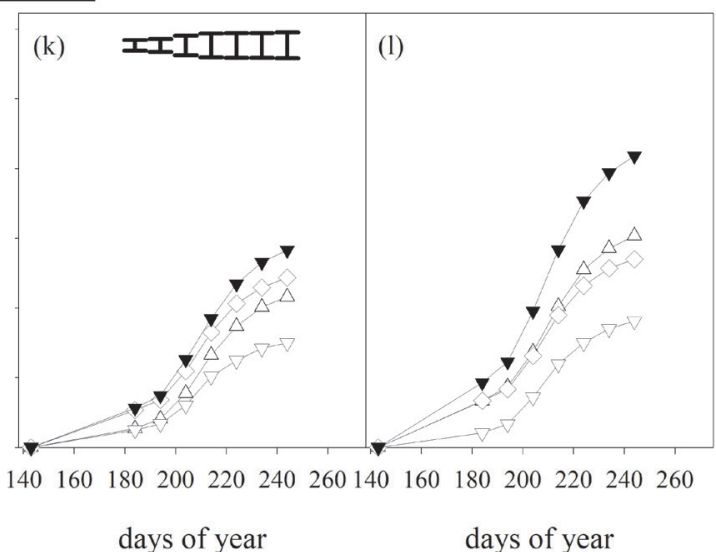

days of year

days of year

Figure 1. Total above-ground dry matter $\left(\mathrm{AGDM}_{\mathrm{T}}\right)(\mathrm{a}-\mathrm{d})$ and above-ground dry matter of fenugreek $\left(\mathrm{AGDM}_{\mathrm{F}}\right)(\mathrm{e}-\mathrm{h})$ and buckwheat $\left(\mathrm{AGDM}_{\mathrm{B}}\right)$ $(\mathrm{i}-\mathrm{l})$ at different harvest dates (HD) as affected by crop stand $\times$ fertilizer type in 2014 and 2015. Sole F and Sole B are sole cropping of fenugreek and buckwheat, respectively. F:B (2:1), F:B (1:1) and F:B (1:2) are two rows of fenugreek + one row of buckwheat, one row of fenugreek + one row of buckwheat, and one row of fenugreek + two rows of buckwheat, respectively. Error bars are LSD ( $<<0.05)$; error bars are valid for the graph where they are shown, plus the adjoining right graph.

Abbildung 1. Gesamte oberirdische Biomassse $\left(\right.$ AGDM $\left._{\mathrm{T}}\right)(\mathrm{a}-\mathrm{d})$ und die oberirdische Biomasse von Bockshornklee $\left(\right.$ AGDM $\left._{\mathrm{F}}\right)(\mathrm{e}-\mathrm{h})$ und Buchweizen $\left(\mathrm{AGDM}_{\mathrm{B}}\right)(\mathrm{i}-\mathrm{l})$ zu verschiedenen Ernteterminen (HD) beeinflusst von Pflanzenbestand $\times$ Düngerart in den Jahren 2014 und 2015 . Sole F and Sole B sind die Reinsaaten von Bockshornklee und Buchweizen. F:B (2:1), F:B (1:1) und F:B (1:2) stehen für zwei Reihen Bockshornklee + eine Reihe Buchweizen, eine Reihe Bockshornklee + eine Reihe Buchweizen und eine Reihe Bockshornklee + zwei Reihen Buchweizen. Fehlerbalken zeigen die Grenzdifferenz (LSD, p < 0,05), wobei die Fehlerbalken für die Graphik, in der sie gezeigt werden, sowie in der rechts angrenzenden Graphik gültig sind. 
$\mathrm{F}: \mathrm{B}(1: 1)>\mathrm{F}: \mathrm{B}(1: 2)$. The same observations were made for $\mathrm{CF}$ in 2015, whereas for $\mathrm{BL}$, the ranking of $\mathrm{AGDM}_{\mathrm{F}}$ was: Sole F > F:B (2:1) > F:B (1:1), F:B (1:2). At HD 7, the $\mathrm{AGDM}_{\mathrm{F}}$ was compared to Sole F at $71 \%$ for F:B $(2: 1)$, $45 \%$ for $\mathrm{F}: \mathrm{B}(1: 1)$ and $33 \%$ for $\mathrm{F}: \mathrm{B}(1: 2)$ (means over both fertilizers and both years) (Figures $1 \mathrm{~g}-\mathrm{h}$ ).

In 2014, from HD 1 onward, the $\mathrm{AGDM}_{\mathrm{F}}$ of Sole F was higher with $\mathrm{BL}$ than with $\mathrm{CF}$, whereas the $\mathrm{AGDM}_{\mathrm{F}}$ of other crop stands did not differ between fertilizer treatments. In 2015, at $\mathrm{HD} 7, \mathrm{BL}$ resulted in a higher $\mathrm{AGDM}_{\mathrm{F}}$ with F:B (1:2) compared to CF. At HD 7, BL resulted in an increase of $A_{G D M}$ by $17 \%$ in 2014 and $5 \%$ in 2015, compared to CF (means overall crop stands).

A significant interaction of crop stand $\times$ fertilizer type was observed for $\mathrm{AGDM}_{\mathrm{B}}$ at all the harvest dates in both years (Figures $1 \mathrm{i}-\mathrm{l}$ ). Sole $\mathrm{B}$ had the highest $\mathrm{AGDM}_{\mathrm{B}}$ in BL treatments in 2014 and with CF and BL in 2015, but not with CF in 2014, since the F:B (2:1) showed higher values. In 2014, with $\mathrm{CF}$ at $\mathrm{HD} 7, \mathrm{AGDM}_{\mathrm{B}}$ was ranked as follows: $\mathrm{F}: \mathrm{B}(2: 1)>$ Sole B > F:B $(1: 1)>\mathrm{F}: \mathrm{B}(1: 2)$. For the BL, the ranking was as follows: Sole $\mathrm{B}>\mathrm{F}: \mathrm{B}(1: 2), \mathrm{F}: \mathrm{B}(2: 1)>\mathrm{F}: \mathrm{B}$ (1:1). In 2015, at HD 7, independent of fertilizer treatment, the $\mathrm{AGDM}_{\mathrm{B}}$ was ranked as follows: Sole B > F:B $(1: 1), \mathrm{F}: \mathrm{B}(2: 1)>\mathrm{F}: \mathrm{B}(1: 2)$.

The $\mathrm{AGDM}_{\mathrm{B}}$ compared to Sole B at $84 \%$ for F:B $(2: 1)$, $74 \%$ for $\mathrm{F}: \mathrm{B}(1: 1)$ and $59 \%$ for $\mathrm{F}: \mathrm{B}(1: 2)$ (means over both fertilizers and both years). Consequently, the $\mathrm{AGDM}_{\mathrm{B}}$ of $\mathrm{F}: \mathrm{B}(2: 1)$ and $\mathrm{F}: \mathrm{B}(1: 1)$ was higher than the share of buckwheat in the sowing ratio (i.e., $33 \%$ or $50 \%$, respectively, of Sole B); whereas, the $\mathrm{AGDM}_{\mathrm{B}}$ of F:B (1:2) was slightly below its sowing ratio share (66\%). In 2014, from HD 1 onward, the $\mathrm{AGDM}_{\mathrm{B}}$ was higher with $\mathrm{BL}$ than with $\mathrm{CF}$ for Sole $B$ and $F: B(1: 2)$, but higher with $C F$ than with BL for $\mathrm{F}: \mathrm{B}(2: 1)$, whereas no differences between fertilizer treatments were observed for $\mathrm{F}: \mathrm{B}$ (1:1). In 2015, from HD 1 onward, the BL resulted in a higher $\mathrm{AGDM}_{\mathrm{B}}$ for Sole B and $\mathrm{F}: \mathrm{B}(2: 1)$ for $\mathrm{BL}$ than for $\mathrm{CF}$, whereas no differences between fertilizer treatments were observed for F:B (1:2) and for F:B (1:1). At HD 7, BL resulted in an increase of $\mathrm{AGDM}_{\mathrm{B}}$ by $10 \%$ in 2014 and by $31 \%$ in 2015 compared to CF (means over all crop stands).

\subsection{Crop growth rates}

\subsubsection{Total crop growth rates $\left(\mathrm{CGR}_{\mathrm{T}}\right)$ of crop stands}

The total crop growth rates of crop stands $\left(\mathrm{CGR}_{\mathrm{T}}\right)$ were significantly affected by crop stand $\times$ fertilizer type in both years in four out of six harvest dates (Figures $2 \mathrm{a}-\mathrm{d}$ ). $\mathrm{CGR}_{\mathrm{T}}$ increased with time, reaching the highest values between HD 3-5, and declined thereafter. The $\mathrm{CGR}_{\mathrm{T}}$ was generally the highest between HD 3-4 and HD 4-5 with 25.1 and $24.2 \mathrm{~g} \mathrm{~m}^{-2} \mathrm{~d}^{-1}$, respectively, and lowest between sowing and HD 1 and HD 6-7 with 3.1 and $4.4 \mathrm{~g} \mathrm{~m}^{-2} \mathrm{~d}^{-1}$, respectively (means for all crop stands, fertilizers and years).

The CGR $\mathrm{T}_{\mathrm{T}}$ was generally the highest with a high share of fenugreek in intercrops (F:B $(2: 1)$ ), followed by Sole F and F:B (1:1); the lowest $\mathrm{CGR}_{\mathrm{T}}$ was observed for Sole B and $F: B(1: 2)$. The mean $\mathrm{CGR}_{\mathrm{T}}$ for pure crop stands between sowing and HD 7 were as follows: 13.1 (Sole F) and 11.6 $\mathrm{g} \mathrm{m}^{-2} \mathrm{~d}^{-1}$ (Sole B) and for intercrops: 18.6 (F:B (2:1)), 14.0 (F:B (1:1)) and 11.1 (F:B (1:2)) $\mathrm{g} \mathrm{m}^{-2} \mathrm{~d}^{-1}$ (means over both fertilizers and both years).

The mean $\mathrm{CGR}_{\mathrm{T}}$ between sowing and $\mathrm{HD} 7$ was higher by $14 \%$ with BL $\left(14.6 \mathrm{~g} \mathrm{~m}^{-2} \mathrm{~d}^{-1}\right)$ than with CF $\left(12.8 \mathrm{~g} \mathrm{~m}^{-2} \mathrm{~d}^{-1}\right)$ (means overall crop stands and both years).

\subsubsection{Crop growth rates of fenugreek $\left(\mathrm{CGR}_{\mathrm{F}}\right)$ or buck- wheat $\left(\mathrm{CGR}_{\mathrm{B}}\right)$}

The crop growth rates of fenugreek $\left(\mathrm{CGR}_{\mathrm{F}}\right)$ were in both years in all sampling intervals significantly affected by crop stand $\times$ fertilizer type (Figures $2 \mathrm{e}-\mathrm{h}$ ). The $\mathrm{CGR}_{\mathrm{F}}$ increased with crop growth reaching the highest values between HD 4-5 (at $16.7 \mathrm{~g} \mathrm{~m}^{-2} \mathrm{~d}^{-1}$ ) before declining again; the lowest values were between sowing and HD 1 and HD 6-7 with 0.3 and $2.7 \mathrm{~g} \mathrm{~m}^{-2} \mathrm{~d}^{-1}$, respectively (means overall crop stands, fertilizers and years).

The $\mathrm{CGR}_{\mathrm{F}}$ were generally the highest with Sole F and diminished with a decreasing share of fenugreek in the intercrops. The mean $\mathrm{CGR}_{\mathrm{F}}$ for Sole $\mathrm{F}$ between sowing and HD 7 was $13.1 \mathrm{~g} \mathrm{~m}^{-2} \mathrm{~d}^{-1}$ and for fenugreek in $\mathrm{F}: \mathrm{B}(2: 1)$, $\mathrm{F}: \mathrm{B}(1: 1)$ and $\mathrm{F}: \mathrm{B}(1: 2)$ was $9.0,5.8$ and $4.3 \mathrm{~g} \mathrm{~m}^{-2} \mathrm{~d}^{-1}$, respectively (means over both fertilizers and both years); which represents $69 \%, 44 \%$ and $34 \%$ of Sole F. Consequently, the $\mathrm{CGR}_{\mathrm{F}}$ of fenugreek in intercrops reflected its sowing share (compared to Sole F). The mean $\mathrm{CGR}_{\mathrm{F}}$ from sowing to HD 7 was $10 \%$ higher with BL $\left(8.5 \mathrm{~g} \mathrm{~m}^{-2} \mathrm{~d}^{-1}\right)$ than with CF $\left(7.7 \mathrm{~g} \mathrm{~m}^{-2} \mathrm{~d}^{-1}\right)$ (means overall crop stands and both years).

The crop growth rates of buckwheat $\left(\mathrm{CGR}_{\mathrm{B}}\right)$ were in most sampling intervals significantly affected by crop stand $x$ fertilizer type in both years (Figures $2 \mathrm{i}-\mathrm{l}$ ). The $\mathrm{CGR}_{\mathrm{B}}$ increased with crop growth reaching the highest values between HD 3-5 (15.2 $\left.\mathrm{g} \mathrm{m}^{-2} \mathrm{~d}^{-1}\right)$ before declining again; lowest values were observed between sowing and HD 1 with $3.5 \mathrm{~g} \mathrm{~m}^{-2} \mathrm{~d}^{-1}$ (means overall crop stands, fertilizers and years). 
$\underline{2014}$

$\underline{2015}$

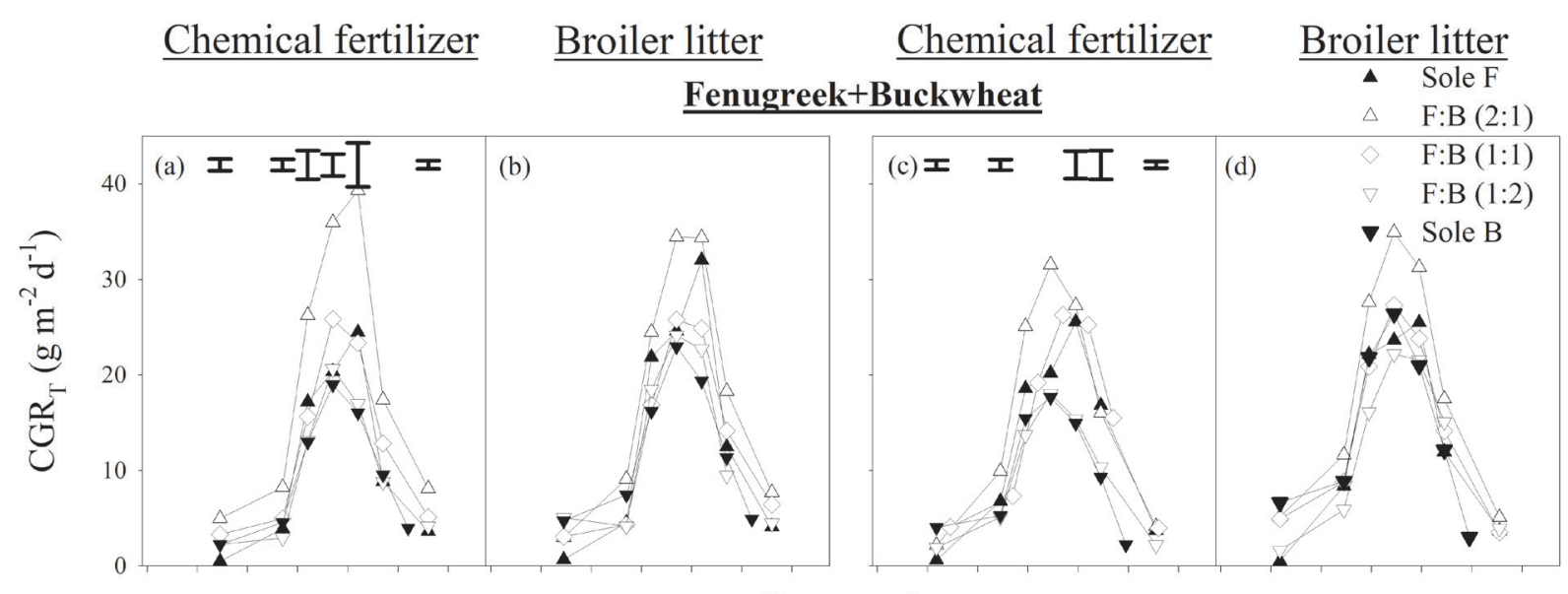

Fenugreek

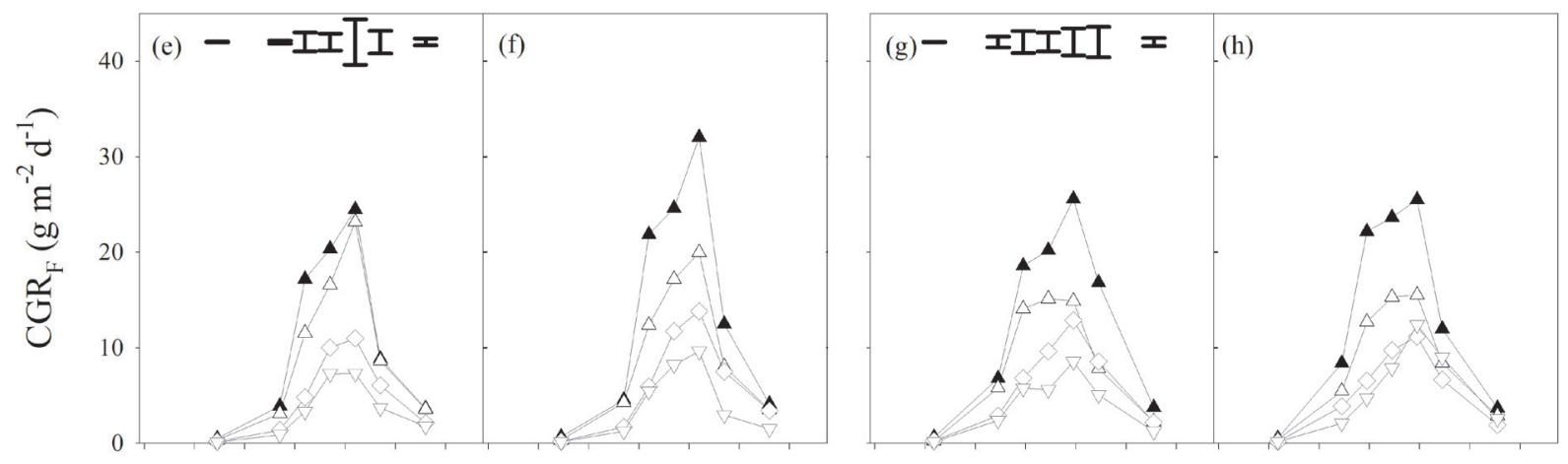

Buckwheat
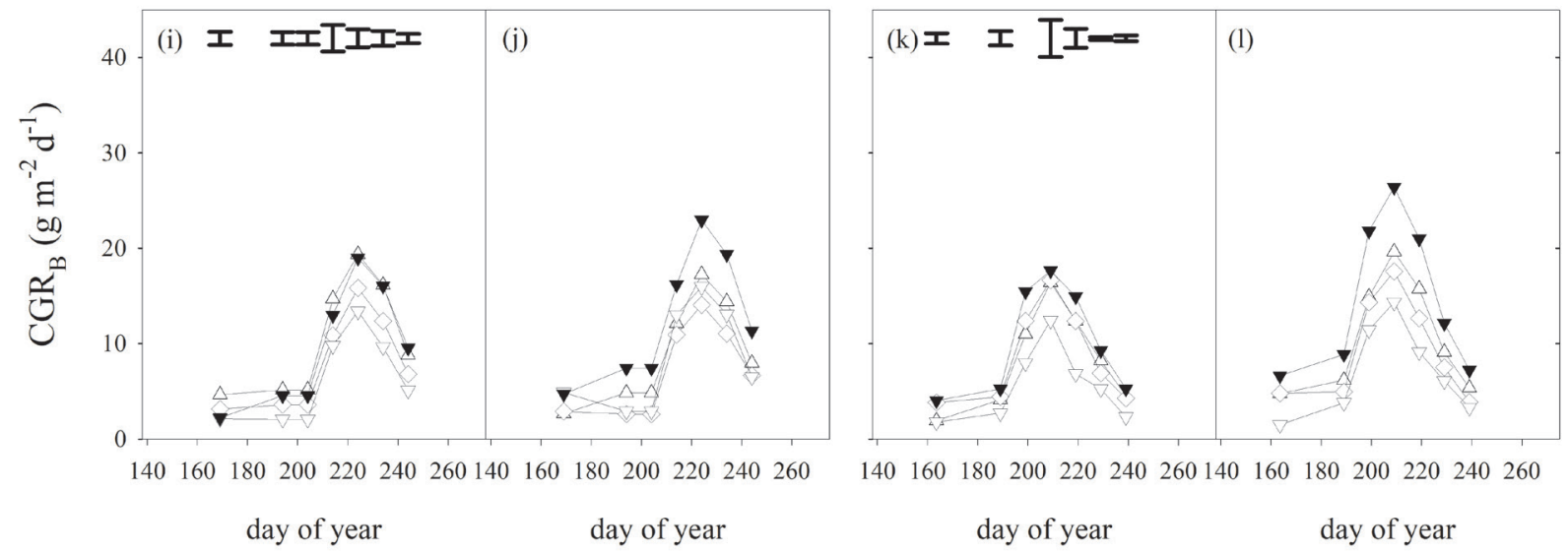

Figure 2. Total crop growth rates $\left(\mathrm{CGR}_{\mathrm{T}}\right)(\mathrm{a}-\mathrm{d})$ and crop growth rates of fenugreek $\left(\mathrm{CGR}_{\mathrm{F}}\right)(\mathrm{e}-\mathrm{h})$ or buckwheat $\left(\mathrm{CGR}_{\mathrm{B}}\right)(\mathrm{i}-\mathrm{l})$ between different harvest dates (HD) as affected by crop stand $\times$ fertilizer type in 2014 and 2015. Error bars are LSD $(p<0.05)$; error bars are valid for the graph where they are shown, plus the adjoining right graph. See Figure 1 for description of treatments.

Abbildung 2. Gesamte Wachstumsraten $\left(\mathrm{CGR}_{\mathrm{T}}\right)(\mathrm{a}-\mathrm{d})$ und die Wachstumsraten von Bockshornklee $\left(\mathrm{CGR}_{\mathrm{F}}\right)(\mathrm{e}-\mathrm{h})$ und Buchweizen $\left(\mathrm{CGR}_{\mathrm{B}}\right)(\mathrm{i}-1) \mathrm{zwis}$ chen verschiedenen Ernteterminen (HD) beeinflusst von Pflanzenbestand $\times$ Düngerart in den Jahren 2014 und 2015. Fehlerbalken zeigen die Grenzdifferenz (LSD, p < 0,05), wobei die Fehlerbalken für die Graphik, in der sie gezeigt werden, sowie in der rechts angrenzenden Graphik gültig sind. Siehe Abbildung 1 für die Beschreibung der Behandlungen. 
The $\mathrm{CGR}_{\mathrm{B}}$ were generally highest with Sole B. The mean $\mathrm{CGR}_{\mathrm{B}}$ for Sole B between sowing and HD 7 was at $11.9 \mathrm{~g}$ $\mathrm{m}^{-2} \mathrm{~d}^{-1}$ and for buckwheat in F:B (2:1), F:B (1:1) and F:B (1:2) was 9.7, 8.3 and $6.9 \mathrm{~g} \mathrm{~m}^{-2} \mathrm{~d}^{-1}$, respectively (means over both fertilizers and both years), which represents $81 \%, 70 \%$ and $58 \%$ compared to Sole B. Thus, the $\mathrm{CGR}_{\mathrm{B}}$ in the intercrops $\mathrm{F}: \mathrm{B}(2: 1)$ and $\mathrm{F}: \mathrm{B}(1: 1)$ was considerably higher than its sowing share (compared to Sole B).

The mean CGR $_{\mathrm{B}}$ from sowing to HD 7 was higher by $18 \%$ for BL $\left(10.0 \mathrm{~g} \mathrm{~m}^{-2} \mathrm{~d}^{-1}\right)$ than for CF $\left(8.5 \mathrm{~g} \mathrm{~m}^{-2} \mathrm{~d}^{-1}\right)$ (means overall crop stands and both years).

\subsection{Relative growth rates}

\subsubsection{Total relative growth rates $\left(\mathrm{RGR}_{\mathrm{T}}\right)$ of crop stands}

The total relative growth rates of fenugreek-buckwheat $\left(\right.$ RGR $\left._{\mathrm{T}}\right)$ were generally highest between HD 2-3 before declining until the final harvest (Figures $3 \mathrm{a}-\mathrm{d}$ ). The highest value was $76.4 \mathrm{mg} \mathrm{g}^{-1} \mathrm{~d}^{-1}$ (between HD 1-2) and the lowest values were 3.9 and $4.2 \mathrm{mg} \mathrm{g}^{-1} \mathrm{~d}^{-1}$ between HD 5-6 and HD 6-7, respectively (means overall crop stands, fertilizers and years).

The mean $\mathrm{RGR}_{\mathrm{T}}$ between HD 1-7 was highest for Sole F $\left(61.1 \mathrm{mg} \mathrm{g}^{-1} \mathrm{~d}^{-1}\right)$ and lowest for Sole B (27.9 $\left.\mathrm{mg} \mathrm{g}^{-1} \mathrm{~d}^{-1}\right)$. The intercrops showed the following values: 35.0 ( $\mathrm{F}: \mathrm{B}$ $(2: 1)), 32.4(\mathrm{~F}: \mathrm{B}(1: 1))$ and $34.9(\mathrm{~F}: \mathrm{B}(1: 2)) \mathrm{mg} \mathrm{g}^{-1} \mathrm{~d}^{-1}$ (means over both fertilizers and both years).

The mean $\mathrm{RGR}_{\mathrm{T}}$ from HD 1-7 was 3.6\% higher for CF (39.0 $\mathrm{mg} \mathrm{g}^{-1} \mathrm{~d}^{-1}$ ) than for BL (37.6 $\left.\mathrm{mg} \mathrm{g}^{-1} \mathrm{~d}^{-1}\right)$ (means overall crop stands and both years).

\subsubsection{Relative growth rate of fenugreek $\left(R_{G} R_{F}\right)$ or buckwheat $\left(\mathrm{RGR}_{\mathrm{B}}\right)$}

The relative growth rate of fenugreek $\left(\mathrm{RGR}_{\mathrm{F}}\right)$ was highest between HD 2-3 in $2014\left(128.2 \mathrm{mg} \mathrm{g}^{-1} \mathrm{~d}^{-1}\right)$ and HD 1-2 in 2015 (159.2 $\mathrm{mg} \mathrm{g}^{-1} \mathrm{~d}^{-1}$ ) (Figures $3 \mathrm{e}-\mathrm{h}$ ). Then $\mathrm{RGR}_{\mathrm{F}}$ declined until the final harvest. The lowest values of $R_{G R}$ were observed between HD 6-7 with $5.7 \mathrm{mg} \mathrm{g}^{-1} \mathrm{~d}^{-1}$ (means over all crop stands, fertilizers and years).

The mean RGR $_{\mathrm{F}}$ between HD 1-7 for Sole F, F:B (2:1), $\mathrm{F}: \mathrm{B}(1: 1)$ and $\mathrm{F}: \mathrm{B}(1: 2)$ were $61.2,65.1,67.5$ and $66.5 \mathrm{mg}$ $\mathrm{g}^{-1} \mathrm{~d}^{-1}$, respectively. Thus, the $\mathrm{RGR}_{\mathrm{F}}$ for $\mathrm{F}: \mathrm{B}(2: 1), \mathrm{F}: \mathrm{B}$ $(1: 1)$ and $F: B(1: 2)$ was higher by $6.4 \%, 10.3 \%$ and $8.6 \%$, respectively compared with Sole F (means over both fertilizers and both years). Regarding fertilizer, both CF and BL had a mean $\mathrm{RGR}_{\mathrm{F}}$ between HD 1-7 of $64.9 \mathrm{mg} \mathrm{g}^{-1} \mathrm{~d}^{-1}$ (means overall crop stands and both years).
The relative growth rate of buckwheat $\left(\mathrm{RGR}_{\mathrm{B}}\right)$ was highest between HD 2-3 (55.1 $\left.\mathrm{mg} \mathrm{g}^{-1} \mathrm{~d}^{-1}\right)$ and declined with time to have the lowest values between HD 6-7 $(7.0 \mathrm{mg}$ $\left.\mathrm{g}^{-1} \mathrm{~d}^{-1}\right)$ (means over all crop stands, fertilizers and years) (Figures $3 \mathrm{i}-1$ ).

The mean RGR $_{B}$ between HD 1-7 for Sole B, F:B (2:1), $\mathrm{F}: \mathrm{B}(1: 1)$ and $\mathrm{F}: \mathrm{B}(1: 2)$ was $29.2,30.2,26.0$ and $29.8 \mathrm{mg}$ $\mathrm{g}^{-1} \mathrm{~d}^{-1}$, respectively. Thus, the $\mathrm{RGR}_{\mathrm{B}}$ for $\mathrm{F}: \mathrm{B}(2: 1)$ and $\mathrm{F}: \mathrm{B}$ (1:2) were higher by $3.1 \%$ and $1.8 \%$ whereas for $\mathrm{F}: \mathrm{B}(1: 1)$ lower by $11.0 \%$ compared with Sole B (means over both fertilizers and both years). Regarding fertilizer, $\mathrm{CF}$ and $\mathrm{BL}$ had a mean $\mathrm{RGR}_{\mathrm{B}}$ between HD 1-7 of 29.8 and $27.8 \mathrm{mg}$ $\mathrm{g}^{-1} \mathrm{~d}^{-1}$, respectively (means over all crop stands and both years). Thus, the $\mathrm{RGR}_{\mathrm{B}}$ with CF was by $6.8 \%$ higher than with using BL.

\subsection{Land equivalent ratios}

\subsubsection{Total land equivalent ratios of above-ground dry matter (AGDM-LER T $_{\mathrm{T}}$ of crop stands}

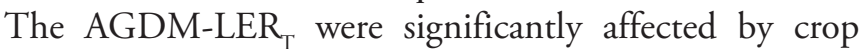
stand $\times$ fertilizer type in seven (2014) and in four (2015) out of seven harvest dates (Figures $4 \mathrm{a}-\mathrm{d}$ ). The AGDM$\mathrm{LER}_{\mathrm{T}}$ were generally highest at HD 1 with 1.27 and lowest at HD 3 with 1.18 (means over all crop stands, fertilizers and years). The mean AGDM-LER $\mathrm{T}_{\mathrm{T}}$ between HD 1-7 for $\mathrm{F}: \mathrm{B}(2: 1), \mathrm{F}: \mathrm{B}(1: 1)$ and F:B (1:2) were 1.56, 1.19 and 0.91 , respectively (means over both fertilizers and both years). At HD 7, the AGDM-LER ${ }_{\mathrm{T}}$ were for F:B (2:1), F:B $(1: 1)$ and $F: B(1: 2)$ were $1.55,1.19$ and 0.98 , respectively (means over both fertilizers and both years).

The mean AGDM-LER , between HD 1-7 was by $28.9 \%$ higher with $\mathrm{CF}$ than with $\mathrm{BL}$ and at HD 7 by $17.5 \%$ higher with CF than with BL (means overall crop stands and both years).

\subsubsection{Partial land equivalent ratio of above-ground dry matter (AGDM-LER F $_{\mathrm{F}}$ of fenugreek or buckwheat (AGDM-LER B $^{\text {) }}$}

The AGDM-LER Fas highest at HD 6-7 with 0.49 and lowest between sowing and HD 1 with 0.37 (means overall crop stands, fertilizers and years). The mean AGDM-LER between HD 1-7 for F:B (2:1), F:B (1:1) and F:B (1:2) were $0.68,0.38$ and 0.28 , respectively (means over both fertilizers and both years). For the fertilizer type, the mean AGDM-LER between HD 1-7 was by $6.6 \%$ higher with $\mathrm{CF}$ than with $\mathrm{BL}$ (means over all crop stands and both years) (Figures $4 \mathrm{e}-\mathrm{h}$ ). 


\section{Chemical fertilizer Broiler litter $\quad$ Chemical fertilizer Broiler litter}

Fenugreek+Buckwheat
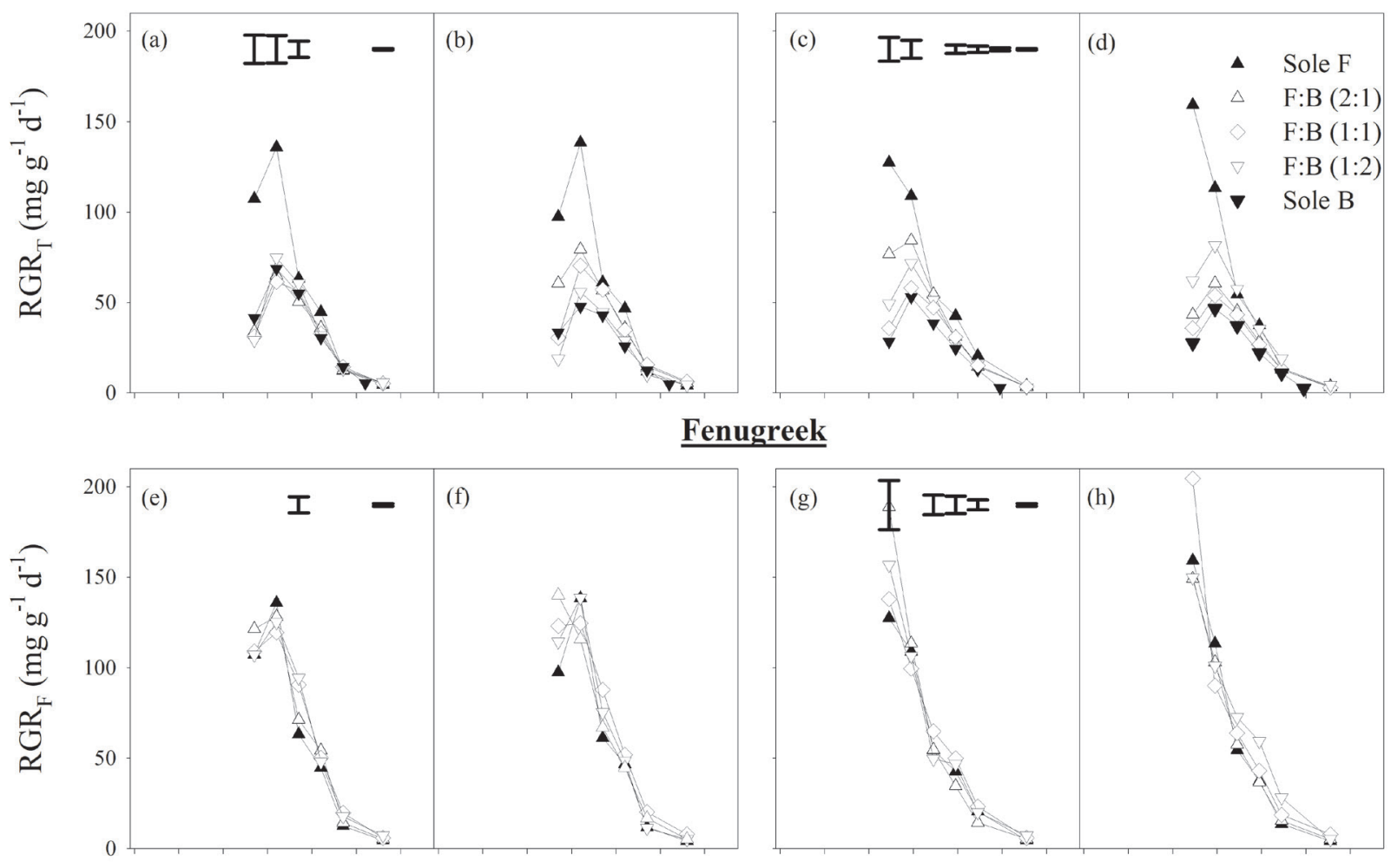

Buckwheat

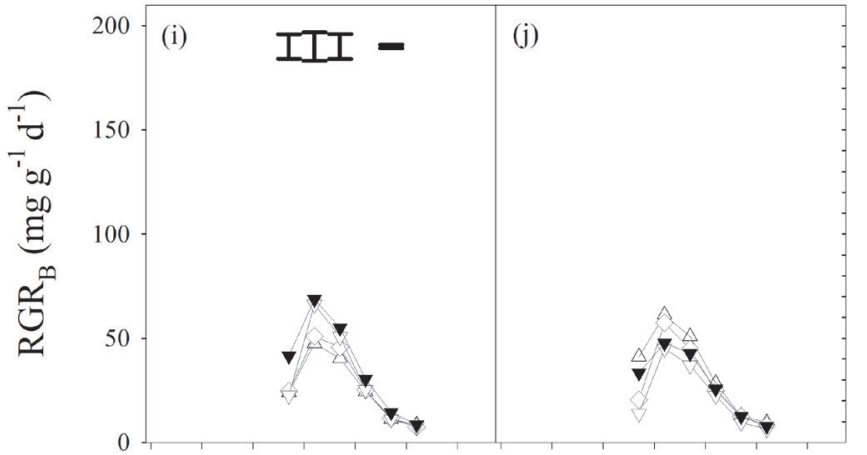

$140160180200220240260140 \quad 160 \quad 180200220240 \quad 260$

day of year

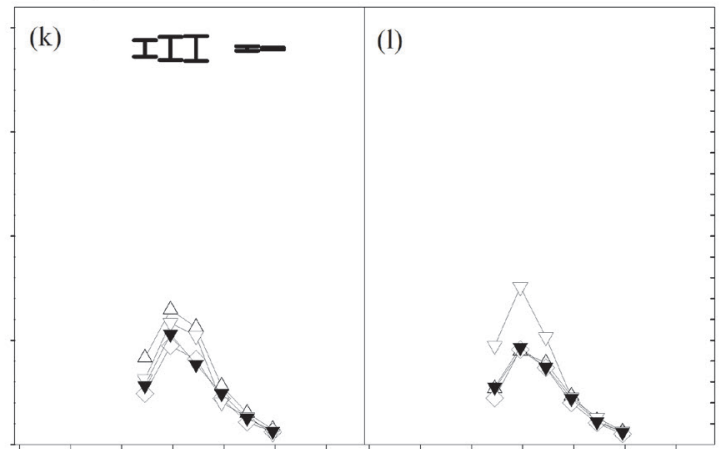

$140160180200220240260140 \quad 160 \quad 180200220240 \quad 260$

day of year

day of year

Figure 3. Total relative growth rates $\left(\mathrm{RGR}_{\mathrm{T}}\right)(\mathrm{a}-\mathrm{d})$ and relative growth rate of fenugreek $\left(\mathrm{RGR}_{\mathrm{F}}\right)(\mathrm{e}-\mathrm{h})$ or buckwheat $\left(\mathrm{RGR}_{\mathrm{B}}\right)(\mathrm{i}-\mathrm{l})$ at different harvest dates (HD) as affected by crop stand $\times$ fertilizer type in 2014 and 2015. Error bars are LSD ( $<<0.05)$; error bars are valid for the graphs where they are shown, plus the adjoining right graph. See Figure 1 for description of treatments.

Abbildung 3. Gesamte relative Wachstumsraten $\left(\mathrm{RGR}_{\mathrm{T}}\right)(\mathrm{a}-\mathrm{d})$ und die relative Wachstumsraten von Bockshornklee $\left(\mathrm{RGR}_{\mathrm{F}}\right)(\mathrm{e}-\mathrm{h})$ und Buchweizen $\left(\mathrm{RGR}_{\mathrm{B}}\right)(\mathrm{i}-\mathrm{l})$ zwischen verschiedenen Ernteterminen (HD) beeinflusst von Pflanzenbestand $\times$ Düngerart in den Jahren 2014 und 2015 . Fehlerbalken zeigen die Grenzdifferenz (LSD, p < 0,05), wobei die Fehlerbalken für die Graphik, in der sie gezeigt werden, sowie in der rechts angrenzenden Graphik gültig sind. Siehe Abbildung 1 für die Beschreibung der Behandlungen. 


\section{Chemical fertilizer $\quad$ Broiler litter $\quad$ Chemical fertilizer $\quad$ Broiler litter}

Fenugreek+Buckwheat
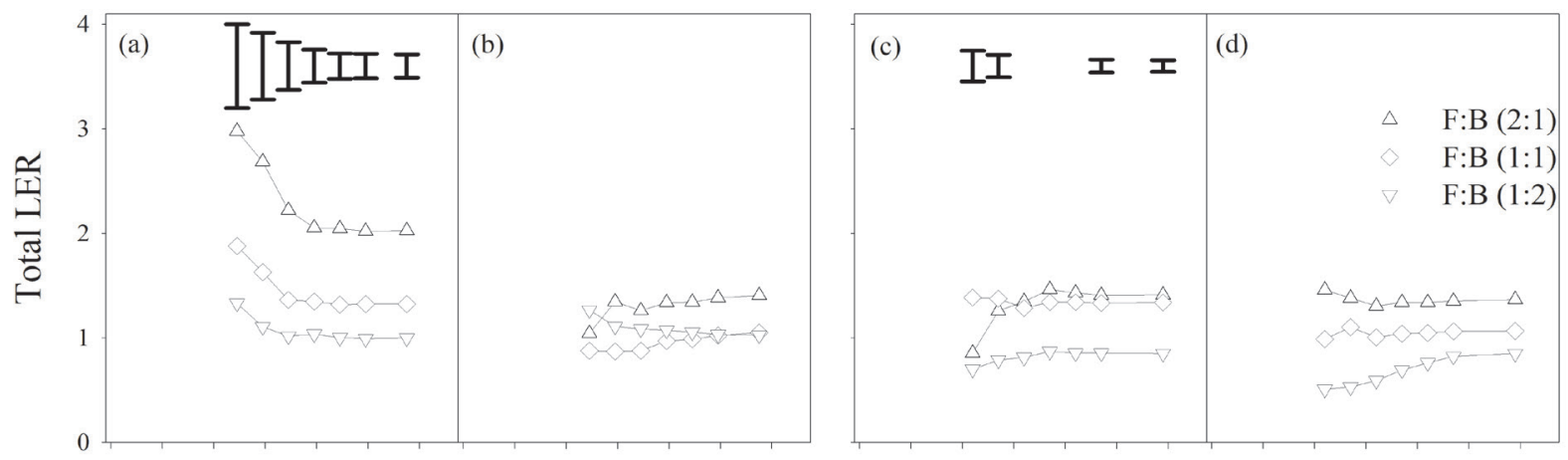

$\underline{\text { Fenugreek }}$
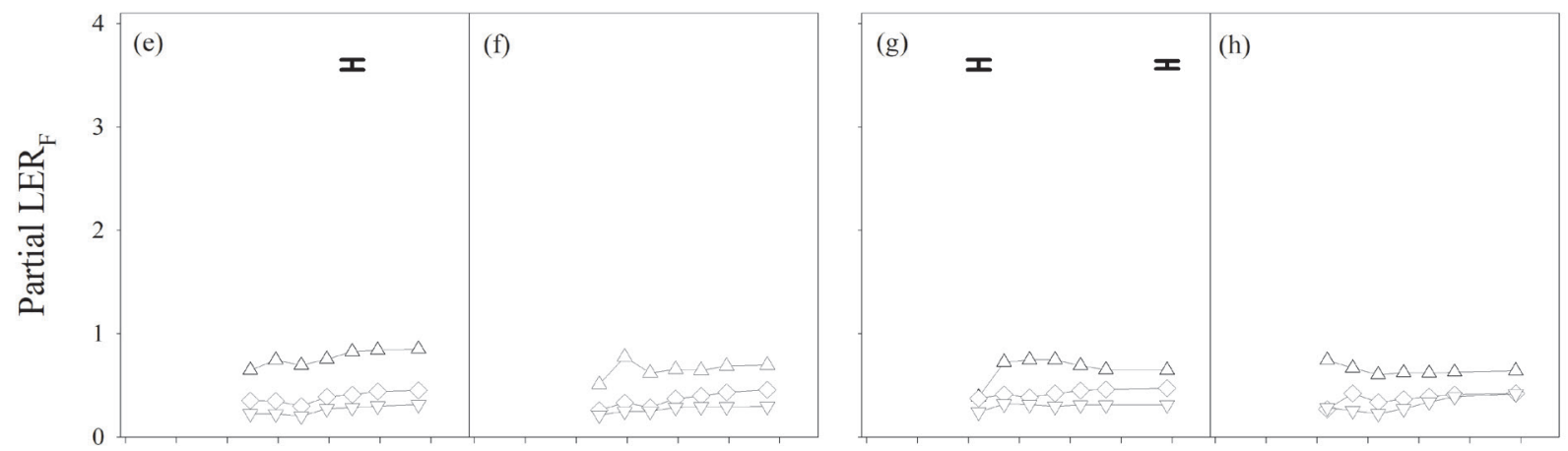

\section{Buckwheat}
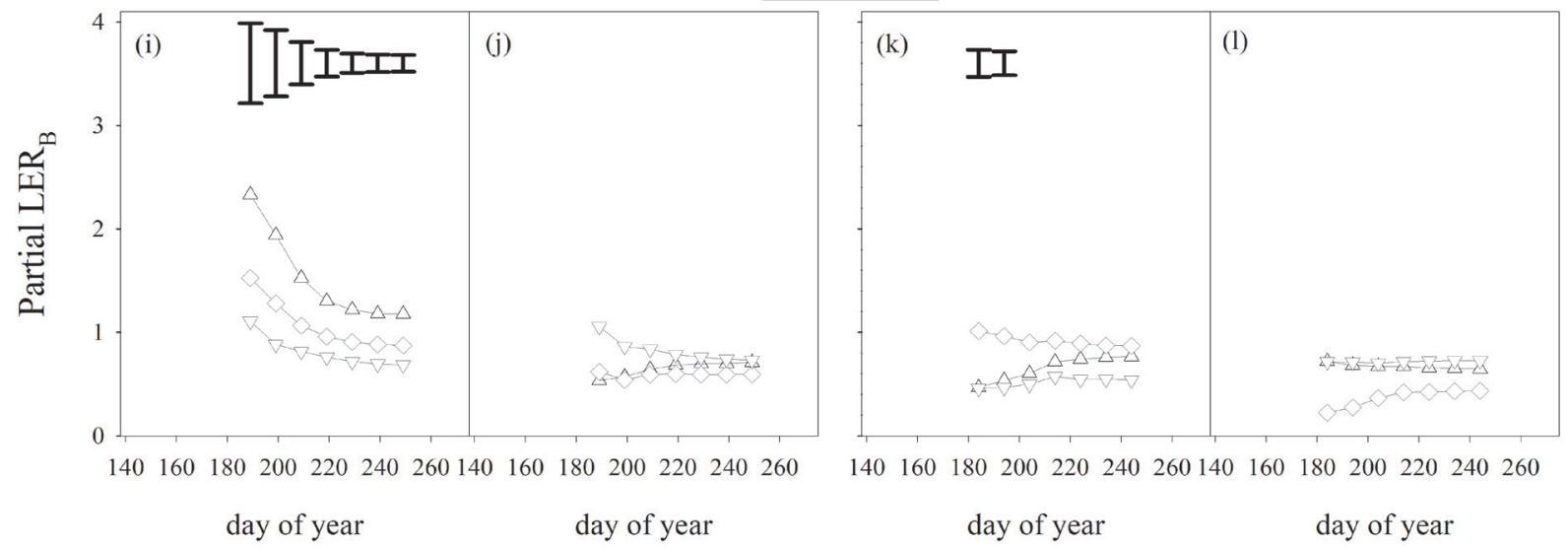

Figure 4. Total land equivalent ratio $\left(\mathrm{LER}_{\mathrm{T}}\right)(\mathrm{a}-\mathrm{d})$ and partial land equivalent ratio of fenugreek $\left(\mathrm{LER}_{\mathrm{F}}\right)(\mathrm{e}-\mathrm{h})$ or buckwheat $\left(\mathrm{LER}_{\mathrm{B}}\right)(\mathrm{i}-\mathrm{l})$ at different harvest dates (HD) as affected by crop stand $\times$ fertilizer type in 2014 and 2015. Error bars are LSD $(\mathrm{p}<0.05)$; error bars are valid for the graph where they are shown, plus the adjoining right graph. See Figure 1 for description of treatments.

Abbildung 4. Gesamte Flächenäquivalenz $\left(\operatorname{LER}_{\mathrm{T}}\right)(\mathrm{a}-\mathrm{d})$ und die Flächenäquivalenz von Bockshornklee $\left(\mathrm{LER}_{\mathrm{F}}\right)(\mathrm{e}-\mathrm{h})$ und Buchweizen $\left(\mathrm{LER}_{\mathrm{B}}\right)(\mathrm{i}-\mathrm{l}) \mathrm{zu}$ verschiedenen Ernteterminen (HD) beeinflusst von Pflanzenbestand × Düngerart in den Jahren 2014 und 2015. Fehlerbalken zeigen die Grenzdifferenz (LSD, p < 0,05), wobei die Fehlerbalken für die Graphik, in der sie gezeigt werden, sowie in der rechts angrenzenden Graphik gültig sind. Siehe Abbildung 1 für die Beschreibung der Behandlungen. 
The AGDM-LER ${ }_{B}$ was the highest between sowing and HD 1 with 0.90 and lowest at HD 6-7 with 0.73 (means over all crop stands, fertilizers and years). The mean AGDM-LER $_{\mathrm{B}}$ between HD 1-7 for F:B (2:1), F:B (1:1) and $\mathrm{F}: \mathrm{B}(1: 2)$ were $0.87,0.74$ and 0.72 , respectively (means over both fertilizers and both years). For the fertilizer type, the mean AGDM-LER ${ }_{\mathrm{B}}$ between HD 1-7 was by $43.9 \%$ higher for $\mathrm{CF}$ than for BL (means over all crop stands and both years) (Figures $4 \mathrm{i}-\mathrm{l}$ ).

\section{Discussion}

A higher $\mathrm{AGDM}_{\mathrm{T}}$ could be achieved by intercropping fenugreek and buckwheat with a medium to high share of fenugreek and a low to medium share of buckwheat (F:B (2:1) and $\mathrm{F}: \mathrm{B}(1: 1))$ compared to the pure stands of the two crops in both years. The $\mathrm{AGDM}_{\mathrm{T}}$ was higher than for pure stands for F:B (1:1) and F:B (2:1) amended with BL and for F:B (2:1) amended with CF. Similar to these results, Wasaya et al. (2013) have reported for wheat-fenugreek intercrops a yield increase of $19 \%$ to $38 \%$ compared to sole crops, with the lower increase obtained in intercrops using a 1:1 wheat-fenugreek share, whereas the higher increase was obtained in intercrops using a 1:3 wheat-fenugreek share. Similarly, Osman and Nersoyan (1986) reported that the highest dry matter yields were observed with a high proportion of the legume in cereal-common vetch intercrops grown for forage production.

At the final harvest, the distribution of the AGDM of fenugreek was similar with its sowing shares. Whereas, the distribution of the AGDM of buckwheat was in F:B $(2: 1)$ and $\mathrm{F}: \mathrm{B}(1: 1)$ intercrops higher compared to its initial sowing share. This indicates, that neither competition nor growth promotion were observed for fenugreek through intercropping, whereas the growth of individual buckwheat plants was enhanced by intercropping (compared to individual buckwheat plants in pure stands) in intercrops where buckwheat was grown with a low to medium share.

Advantages of intercropping are attributed to a more efficient utilization of finite resources such as light, nutrients and water (Musa et al., 2010). Yield advantages have been realized mainly due to the higher AGDM production of buckwheat in the intercrops (compared to its sowing ratio). The $\mathrm{AGDM}_{\mathrm{F}}$ in intercrops was mainly governed by its sowing ratio, whereas the $\mathrm{AGDM}_{\mathrm{B}}$ appeared to be governed by less interspecific competition and/or growth promotion processes (Hauggaard-Nielsen et al., 2008). Yield increases in intercrops have previously been explained by the increased growth of the non-legume component when the non-legumes were taller than the legumes (Rerkasem et al., 1988). This provided buckwheat plants with more available radiation for an improved photosynthesis (Nasiri et al., 2014) due to their taller growth than fenugreek (data not shown). Furthermore, there is a higher $\mathrm{N}$ availability for the individual non-legume plant in intercrops with low non-legume density (compared to the pure stand) (Kübler et al., 2008).

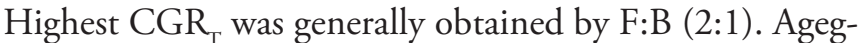
nehu et al. (2006) reported that a high seeding ratio of the legume decreased the growth rate of the cereal in intercrops. Contrary to those findings, we observed the highest $\mathrm{CGR}_{B}$ within the intercrops with highest $\mathrm{F}$ and lowest $\mathrm{B}$ share. The $\mathrm{CGR}_{\mathrm{F}}$ was lower in intercrops. This is in agreement with Ghosh (2004) who reported that the crop growth rate of groundnut was significantly lower in groundnut-pearl millet intercrops than for sole groundnut. The relative growth rates were generally highest between HD 1-3 before declining until final harvest. These results are similar to findings of Neugschwandtner et al. (2013) who also observed that the RGR declined with time. This is due to the increase of the share of non-assimilatory tissues (e.g., stems, inflorescences) with time (Nogueira et al., 1994). The RGR of fenugreek from HD 1-7 was much higher than the $R_{G R}$ principally because the $A_{G D M}$ was considerably higher at the first harvest date (HD 1) than the $\mathrm{AGDM}_{\mathrm{F}}$ (the final AGDMs do not differ very much). Consequently, the final yields could be obtained in a similar range despite the lower $\mathrm{RGR}_{B}$ from HD 1-7.

Both crops showed a similar growth pattern in 2015; their growth rates were highest between HD 4-5 and the relative crop growth rates were highest between HD 2-3 (but between HD 1-2 in 2014). Anyhow, intercrops are most productive when the partner differ greatly in their growth duration as this allows for an asynchronicity of peak resource requirements (Fukai and Trenbath, 1993).

Broiler litter generally led to a higher $\mathrm{AGDM}_{\mathrm{T}} \mathrm{AGDM}_{\mathrm{F}}$ was higher with BL than with CF only in Sole F, whereas the $\mathrm{AGDM}_{\mathrm{F}}$ of the intercrops did not differ between the fertilizer treatments. $\mathrm{AGDM}_{\mathrm{B}}$ was generally higher with $\mathrm{BL}$ than with CF. Consequently, the partly higher AG$\mathrm{DM}_{\mathrm{T}}$ was a result of higher $\mathrm{AGDM}_{\mathrm{B}}$ in the $\mathrm{BL}$ amended intercropped treatments. From our results in the present study, and also the results explained by Salehi et al. (2018), it appears that the broiler litter fertilizer increased $\mathrm{N}$ and $\mathrm{P}$ content of plants and soil fertility more effectively than 
the chemical fertilization that led to better plant development. A higher AGDM production with BL than with $\mathrm{CF}$ could be due to an appropriate supply of soil nutrients by broiler litter which provide an optimum balance between $\mathrm{N}$ and $\mathrm{P}$ in the calcareous soils of the study site (Ghosh et al., 2004; Singh et al., 2009; Fereidooni et al., 2013). Also, Siavoshi et al. (2010) have shown that organic fertilizer resulted in higher yields of rice (Oryza sativa L.) than with chemical fertilizer. As with AGDM, the crop growth rates were generally higher with BL than with CF, whereas RGR were generally higher with $\mathrm{CF}$ than with $\mathrm{BL}$. The reason for that is $\mathrm{AGDM}_{\mathrm{T}}$ at $\mathrm{HD} 1$ was much higher with $\mathrm{BL}$ than with CF. This explains why the RGR was lower for BL than for CF from HD 1-7.

The highest AGDM-LER $\mathrm{T}_{\mathrm{T}}$ were generally achieved with the highest $\mathrm{F}$ and the lowest B share (F:B (2:1)). Similar to our observations, Szumigalski and Van Acker (2008) reported that intercropping produced LER values for dry matter yield that were significantly higher than unity. A value greater than 1.0 indicates a beneficial association between the two crops. In our study, a higher partial AG$\mathrm{DM}^{-L_{E R}}$ and partial AGDM-LER ${ }_{\mathrm{B}}$ were obtained with increasing the share of fenugreek and decreasing the share

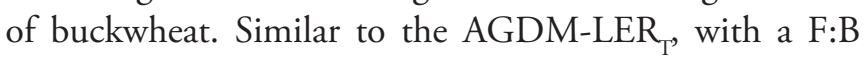
(2:1) the fenugreek and buckwheat accumulated a relatively higher above-ground dry matter.

The main advantage was achieved due to a higher partial LER of buckwheat in early growth stages (especially for buckwheat grown with a low to medium share on the intercrops). A LER > 1 can often be attributed to enhanced nitrogen fixation and nitrogen uptake in intercropping (Salehi et al., 2018). In a previous study, we demonstrated that the seed harvest of fenugreek-buckwheat intercrops obtained similar $\mathrm{LER}_{\mathrm{T}}$ of $>1$ and a higher total and partial LER for both crops were also found with a low to medium share of buckwheat (Salehi et al., 2017b). The AGDM$\mathrm{LER}_{\mathrm{T}}$ was higher with CF than with $\mathrm{BL}$, as with $\mathrm{BL}$, the AGDM at the final harvest was higher than with CF (except for fenugreek in 2015); thus, the advantages through intercrops were lower.

\section{Conclusion}

We observed a higher AGDM and AGDM-LER for intercrops of fenugreek and buckwheat with a medium to high share of fenugreek and a low to medium share of buckwheat compared to their corresponding pure stands grown in semi-arid conditions. Growth analysis revealed that fenugreek produced at all sowing ratios per area and per day similar amounts of AGDM compared to its corresponding share on the sowing ratio; whereas, buckwheat could produce in intercrops with a low to medium share of buckwheat more AGDM per area and per day compared to its share on the sowing ratio. Broiler litter was more effective to enhance $\mathrm{AGDM}_{\mathrm{T}}$ and $\mathrm{CGR}_{\mathrm{T}}$ than chemical fertilizer. Thus, growing fenugreek and buckwheat in suitable intercrops with broiler litter can be beneficial for increasing the biomass productivity of these crops in semi-arid environments.

\section{Acknowledgements}

We are grateful to the Austrian Academy of Science (ÖAW) for awarding a $\mathrm{PhD}$ research scholarship to Aliyeh Salehi and also to the University of Natural Resources and Life Sciences Vienna (BOKU), for hosting Aliyeh Salehi during her research stay.

\section{References}

Agegnehu, G., Ghizaw, A. and W. Sinebo (2006): Yield performance and land-use efficiency of barley and faba bean mixed cropping in Ethiopian highlands. European Journal of Agronomy 25, 202-207.

Ahmadian, A., Ghanbari, A., Siahsar, B., Haydari, M., Ramroodi, M. and S.M. Mousavinik (2011): Study of chamomile's yield and its components under drought stress and organic and inorganic fertilizers using and their residue. Journal of Microbiology and Antimicrobials 3, 23-28.

Alamprese, C., Casiraghi, E. and M.A. Pagani (2007): Development of gluten-free fresh egg pasta analogues containing buckwheat. European Food Research and Technology 225, 205-213.

Alizadeh, P., Fallah, S. and F. Raiesi (2012): Potential N mineralization and availability to irrigated maize in a calcareous soil amended with organic manures and urea under field conditions. International Journal of Plant Production 6, 493-512.

Bajelia, J., Tripathia, S., Kumara, A., Tripathia, A. and R.K. Upadhyayba (2015): Organic manures a convincing source for quality production of Japanese mint (Mentha arvensis L.). Industrial Crops and Products 83, 603-606. 
Bedoussac, L. and E. Justes (2010): The efficiency of a durum wheat-winter pea intercrop to improve yield and wheat grain protein concentration depends on $\mathrm{N}$ availability during early growth. Plant and Soil 330, 19-35.

Betty, R.I. (2008): The many healing virtues of fenugreek. Spice India 1, 17-19.

Branca, G., Lipper, L., McCarthy, N. and M.C. Jolejole (2013): Food security, climate change, and sustainable land management. A review. Agronomy for Sustainable Development 27, 1-16.

Cecilio, A.B., Rezende, B.L.A., Barbosa, J.C. and L.C. Grangeiro (2011): Agronomic efficiency of intercropping tomato and lettuce. Anais da Academia Brasileira de Ciências 83, 1109-1119.

Dadrasan, M., Chaichi, M.R., Pourbabaee, A.A., Yazdani, D. and R. Keshavarz-Afshar (2015): Deficit irrigation and biological fertilizer influence on yield and trigonelline production of fenugreek. Industrial Crops and Products 77, 156-162.

Damour, G., Ozier-Lafontaine, H. and M. Dorel (2012): Simulation of the growth of banana (Musa spp.) cultivated on cover-crop with simplified indicators of soil water and nitrogen availability and integrated plant traits. Field Crops Research 130, 99-108.

Ebrahimi, E., Kaul, H.-P., Neugschwandtner, R.W. and A. Dabbagh Mohammadi Nassab (2017): Productivity of wheat (Triticum aestivum L.) intercropped with rapeseed (Brassica napus L.). Canadian Journal of Plant Science 97, 557-568.

Fereidooni, M., Raiesi, F. and S. Fallah (2013): Ecological restoration of soil respiration, microbial biomass and enzyme activities through broiler litter application in a calcareous soil cropped with silage maize. Ecological Engineering 58, 266-277.

Fukai, S. and B.R. Trenbath (1993): Processes determining intercrop productivity and yields of component crops. Field Crops Research 34, 247-271.

Ghosh, P.K. (2004): Growth, yield, competition and economics of groundnut/cereal fodder intercropping systems in the semi-arid tropics of India. Field Crops Research 88, 227-237.

Ghosh, P.K., Ajay, K.K., Bandyopadhyay, M.C., Manna, K.G., Mandal, A.K. and K.M. Hati (2004): Comparative effectiveness of cattle manure, poultry manure, phosphor compost and fertilizer-NPK on three cropping system in vertisols of semi-arid tropics. II. Dry matter yield, nodulation, chlorophyll content and enzyme activity. Bioresource Technology 95, 85-93.
Ghosh, P.K., Tripathi, A.K., Bandyopadhyay, K.K. and M.C. Manna (2009): Assessment of nutrient competition and nutrient requirement in soybean/sorghum intercropping system. European Journal of Agronomy 31, 43-50.

Gomiero, T., Pimentel, D. and M.G. Paoletti (2011): Is there a need for a more sustainable agriculture? Critical Reviews in Plant Science 30, 6-23.

Halbrecq, B., Romedenne, P. and J.F. Ledent (2005): Evolution of flowering, ripening and seed set in buckwheat (Fagopyrum esculentum Moench): quantitative analysis. European Journal of Agronomy 23, 209-224.

Hamzei, J. and M. Seyyedi (2016): Energy use and inputoutput costs sunflower production in sole and intercropping with soybean under different tillage systems. Soil and Tillage Research 157, 73-82.

Handa, T., Yamaguchi, K., Sono, Y. and K. Yazawa (2005): Effects of fenugreek seed extract in obese mice fed a high fat diet. Bioscience, Biotechnology, and Biochemistry 69, 1186-1188.

Hauggaard-Nielsen, H., Ambus, P. and E.S. Jensen (2001): Interspecific competition, $\mathrm{N}$ use and interference with weeds in pea-barley intercropping. Field Crops Research 70, 101-109.

Hauggaard-Nielsen, H., Jornsgaard, B., Kinane, J. and E.S. Jensen (2008): Grain legume-cereal intercropping: the practical application of diversity, competition and facilitation in arable and organic cropping systems. Renewable Agriculture and Food Systems 23, 3-12.

Hunt, R. (1982): Plant Growth Curves. Functional Approach to Plant Growth Analyses. Edward Arnold, London, UK.

Kalinova, J. and N. Vrchotova (2011): The influence of organic and conventional crop management, variety and year on the yield and flavonoid level in common buckwheat groats. Food Chemistry 127, 602-608.

Kenny, O., Smyth, T.J., Hewage, C.M. and N.P. Brunton (2013): Antioxidant properties and quantitative UPLCMS analysis of phenolic compounds from extracts of fenugreek (Trigonella foenum-graecum) seeds and bitter melon (Momordica charantia) fruit. Food Chemistry 141, 4295-4302.

Khiriya, K.D., Sheoran, R.S. and B.P. Singh (2002): Growth analysis of fenugreek (Trigonella foenum-graecum L.) under various levels of farmyard manure and phosphorus. Journal of Spices and Aromatic Crops 10, 105-110. 
Klimek-Kopyra, A., Kulig, B., Oleksy, A. and T. Zając (2015): Agronomic performance of naked oat (Avena nuda L.) and faba bean intercropping. Chilean Journal of Agricultural Research 75, 168-173.

Klimek-Kopyra, A., Skowera, B., Zając, T. and B. Kulig (2017): Mixed cropping of linseed and legumes as a ecological way to effectively increase oil quality. Romanian Agricultural Research 34, 217-224.

Koyama, M., Nakamura, C. and K. Nakamura (2013): Changes in phenols contents from buckwheat sprouts during growth stage. Journal of Food Science and Technology 50, 86-93.

Kübler, E., Aufhammer, W. and H.-P. Piepho (2006): Mischungsverhältnisse in Getreide-KörnerleguminosenBeständen auf den Kornertrag in Abhängigkeit des Mischungsverhältnisses (Mixing effects in cereal-grain legume stands in dependence of the mixing ratio). Die Bodenkultur 57, 121-130.

Kübler, E., Aufhammer, W. and H.-P. Piepho (2008): Mischungsverhältnisse in Getreide-KörnerleguminosenBeständen auf die Zusammensetzung der Spross- und Kornmassen in Abhängigkeit des Mischungsverhältnisses (Mixing effects in cereal-grain legume stands on the composition of the above ground dry matter yield and the grain yield in dependence of the mixing ratio). Die Bodenkultur 59, 85-94.

Kübler, E., Aufhammer, W. and H.-P. Piepho (2010): Mischungsverhältnisse in Getreide-KörnerleguminosenBeständen auf die N-Akkumulation in den Spross- und Kornmassen in Abhängigkeit des Mischungsverhältnisses (Mixing effects in cereal-grain legume stands on the $\mathrm{N}$-accumulation of the above ground dry matter yield and the grain yield in dependence of the mixing ratio). Die Bodenkultur 61, 19-27.

Lithourgidis, A.S., Dordas, C.A., Damalas, C.A. and D.N. Vlachostergios (2011): Annual intercrops: an alternative pathway for sustainable agriculture. Australian Journal of Crop Science 5, 396-410.

Mead, R. and R.W. Willey (1980): The concept of land equivalent ratio and advantages in yield from intercropping. Experimental Agriculture 16, 217-218.

Mirhashemi, S.M., Koocheki, A., Parsa, M. and M. Nassiri Mahallati (2009): Evaluating the benefit of Ajowan and Fenugreek intercropping in different levels of manure and planting pattern. Irananian Journal of Field Crop Research 1, 269-279.

Musa, M., Leitch, M.H., Iqbal, M. and F.U.H. Sahi (2010): Spatial arrangement affects growth characteristics of barley-pea intercrops. International Journal of Agriculture and Biology 12, 685-690.

Nasiri, A., Nourmohamadi, G., Zandi, P., Siavoshi, M. and S. Dastan (2014): Preliminary evaluations of the yield components and productivity of sole cropped and mix-intercropped sweet corn with berseem clover as influenced by various spatial arrangements. Polish Journal of Agronomy 18, 36-44.

Neugschwandtner, R.W. and H.-P. Kaul (2014): Sowing ratio and $\mathrm{N}$ fertilization affect yield and yield components of oat and pea in intercrops. Field Crops Research 155, 159-163.

Neugschwandtner, R.W. and H-P. Kaul (2015): Nitrogen uptake, use and utilization efficiency by oat-pea intercrops. Field Crops Research 179, 113-119.

Neugschwandtner, R.W. and H-P. Kaul (2016a): Concentrations and uptake of macronutrients by oat and pea in intercrops in response to $\mathrm{N}$ fertilization and sowing ratio. Archives of Agronomy and Soil Science 62, 1236-1249.

Neugschwandtner, R.W. and H-P. Kaul (2016b): Concentrations and uptake of micronutrients by oat and pea in intercrops in response to $\mathrm{N}$ fertilization and sowing ratio. Die Bodenkultur: Journal of Land Management, Food and Environment 67, 1-15.

Neugschwandtner, R.W., Wichmann, S., Gimplinger, D.M., Wagentristl, H. and H-P. Kaul (2013): Chickpea performance compared to pea, barley and oat in Central Europe: Growth analysis and yield. Turkish Journal of Field Crops 18, 179-184.

Nogueira, S.S.S., Nagai, V., Braga, N.R., Do, M., Novo, C.S.S. and M.B.P. Camargo (1994): Growth analysis of chickpea (Cicer arietinum L.). Scientia Agricola 51, 430-435.

Osman, A.E. and N. Nersoyan (1986): Effect of the proportion of species on the yield and quality of forage mixtures, and on the yield of barley in the following year. Experimental Agriculture 22, 345-351.

Peng, S., Buresh, R.J., Huang, J., Zhong, X., Zou, Y., Yang, J., Wang, G., Liu, Y., Tang, Q., Cui, K., Zhang, F. and A. Dobermann (2010): Improving nitrogen fertilization in rice by site-specific $\mathrm{N}$ management. A review. Agronomy for Sustainable Development 30, 649-656.

Petropoulos, A. (Ed.) (2002): Fenugreek: The genus Trigonella. Taylor \& Francis, London and New York, 200 pp.

Raju, J. and R.P. Bird (2006): Alleviation of hepatic steatosis accompanied by modulation of plasma and liver TNF-alpha levels by Trigonella foenum graecum (fenu- 
greek) seeds in Zucker obese (fa/fa) rats. International Journal of Obesity 30, 1298-1307.

Rerkasem, B., Rerkasem, K., Peoples, M.B., Herrigde, B.F. and F.J. Bergersen (1988): Measurement of $\mathrm{N}_{2}$ fixation in maize (Zea mays L.)-rice bean (Vigna umbellata [Thumb.] Ohwi and Onashi). Plant and Soil 108, 151-162.

Salehi, A., Fallah, S. and A. Abbasi Surki (2017a): Effect of urea fertilizer combined with cattle manure on soil $\mathrm{CO}_{2}$ flux, microbial biomass, soil nitrogen, and growth of black cumin (Nigella sativa L.). International Agrophysics 31, 103-116.

Salehi, A., Fallah, S. and H-P. Kaul (2017b): Broiler litter and inorganic fertilizer effects on seed yield and productivity of buckwheat and fenugreek in row intercropping. Archives of Agronomy and Soil Science 63, 1121-1136.

Salehi, A., Mehdi, B., Fallah, S., Kaul, H.-P. and R.W. Neugschwandtner (2018): Integrated fertilization of buckwheat-fenugreek intercrops improves productivity and nutrient use efficiency. Nutrient Cycling in Agroecosystmes 110, 407-425.

Scalise, A., Tortorella, D., Pristeri, A., Petrovičová, B., Gelsomino, A., Lindström, K. and M. Monti (2015): Legume-barley intercropping stimulates soil $\mathrm{N}$ supply and crop yield in the succeeding durum wheat in a rotation under rainfed conditions. Soil Biology and Biochemistry $89,150-161$.

Shrestha, R.K., Lal, R. and B. Rimal (2013): Soil carbon fluxes and balances and soil properties of organically amended no-till corn production systems. Geoderma 197-198, 177-185.

Siavoshi, M., Nasiri, A. and L.L. Shankar (2010): Effect of organic fertilizer on growth and yield components in rice (Oryza sativa L.). Journal of Agricultural Science 3, 217-224.
Singh, Y., Gupta, R.K., Thind, H.S., Singh, B., Singh, V., Singh, G., Singh, J. and J.K. Ladha (2009): Poultry litter as a nitrogen and phosphorous source for the ricewheat cropping system. Biology and Fertility of Soils 45, 701-710.

Stockdale, E.A., Shepherd, M.A., Fortune, S. and S.P. Cuttle (2002): Soil fertility in organic farming systemsfundamentally different? Soil Use and Management 18, 301-308.

Sugár, E., Berzsenyi, Z., Bónis, P. and T. Árendás (2017): Growth analysis of winter wheat cultivars as affected by nitrogen fertilization. Die Bodenkultur: Journal of Land Management, Food and Environment 68, 57-70.

Szumigalski, A.R. and R.C. Van Acker (2008): Land equivalent ratios, light interception, and water use in annual intercrops in the presence or absence of in-crop herbicides. Agronomy Journal 100, 1145-1154.

Tejada, M. and J.L. Gonzales (2008): Influence of two organic amendments on the soil physical properties, soil loses, sediment and runoff water quality. Geoderma 145, 325-334.

Wasaya, A., Ahmad, R., Hassan, F.U., Ansar, M., Manaf, A. and A. Sher (2013): Enhancing crop productivity through wheat (Triticum aestivum L.)-fenugreek intercropping system. Journal of Animimal and Plant Science 23, 210-215.

Yin, X.M., Luo, W., Wang, S.W., Shen, Q.R. and X.H. Long (2014): Effect of nitrogen starvation on the responses of two rice cultivars to nitrate uptake and utilization. Pedosphere 24, 690-698.

Zając, T., Oleksy, A., Stokłosa, A., Klimek-Kopyra, A. and B. Kulig (2013): The development competition and productivity of linseed and pea-cultivars grown in a pure sowing or in a mixture. European Journal of Agronomy 44, 22-31. 